\title{
Environmental fate of chlordecone in coastal habitats: recent studies conducted in Guadeloupe and Martinique (Lesser Antilles)
}

\author{
Dromard Charlotte R. 1, * , Devault Damien 2, 3, Bouchon-Navaro Yolande 1, Allénou Jean-Pierre 4 , \\ Budzinski Hélène ${ }^{2}$, Cordonnier Sébastien ${ }^{1}$, Tapie Nathalie ${ }^{2}$, Reynal Lionel ${ }^{4}$, Lemoine Soazig ${ }^{1}$, \\ Thomé Jean-Pierre ${ }^{5}$, Thouard Emmanuel ${ }^{4}$, Monti Dominique ${ }^{1}$, Bouchon Claude ${ }^{1}$
}

1 Unité Biologie des organismes et écosystèmes aquatiques (BOREA), Université des Antilles, MNHN, Sorbonne UniversitéUniversité de Caen Normandie, CNRS, IRDPointe-à-Pitre, France

2 UMR CNRS 5805 EPOC - OASU, Équipe LPTCUniversité de BordeauxTalence Cedex, France

3 Unité Biologie des organismes et écosystèmes aquatiques (BOREA), Université des Antilles, MNHN,

Sorbonne Université Schœlcher, France

${ }^{4}$ IFREMER, Unité Biodiversité et Environnement de la Martinique Le Robert, France

${ }^{5}$ Laboratoire d'Ecologie Animale et d'Ecotoxicologie (LEAE-CART), Freshwater and Oceanic sciences Unit of reSearch (FOCUS), B6CLiège, Belgium

* Corresponding author : Charlotte R. Dromard, email address : charlotte.dromard@univ-antilles.fr

\begin{abstract}
:
The organochlorine pollution by chlordecone, an insecticide spread in the past in banana plantations, is now recognized as a major ecological, economic, and social crisis in Guadeloupe and Martinique Islands. Due to its physical and chemical properties, this molecule is particularly persistent in the natural environment. Volcanic soil of Guadeloupe and Martinique contain allophanes (amorphous clays), which favor chlordecone trapping due to their structure and physical properties. Thus, with this trapping ability, allophanes serve as a vector allowing chlordecone to contaminate runoff waters and, finally, the sea. In the present publication, several studies recently conducted in the Lesser Antilles have been compiled in order to evaluate the desorption of chlordecone from allophanes when arriving in the estuarine environment and to determine the transfer of chlordecone along marine trophic food webs. The experiments showed that $20 \%$ of the initial quantity of chlordecone was released from allophanes in estuarine conditions and $10 \%$ in the marine environment. These results could explain the high level of contamination found in the suspended organic matter and zooplankton in the coastal areas located downstream of the contaminated watersheds. The contamination of the marine food webs of mangroves, seagrass beds, and coral reefs is dominated by a contamination "by bath" in littoral waters containing chlordecone and by bioamplification seawards.
\end{abstract}

Keywords: Organochlorine pollution, Desorption, Allophane, Zooplankton, Trophic food webs, Bioamplification 


\section{Introduction}

The organochlorine pollution by chlordecone, an insecticide spread in the past in banana plantations, is now recognized as a major ecological, economic and social crisis in the French West Indies. Used between 1972 and 1993 in fields of Guadeloupe and Martinique, chlordecone (commercialized as Kepone® then Curlone®) has been globally banned by the Stockholm Convention on Persistent Pollutant since 2009. This molecule is responsible for toxicological consequences such as an increased risk of prostate cancer, motor skills delays, an increased risk of preterm birth, endocrine disruptions and reproduction impairments (Epstein 1978; Multigner et al. 2010; Boucher et al. 2013; Kadhel et al. 2014; Multigner et al. 2016).

Due to its physical and chemical properties, this hydrophobic molecule has an affinity with soil organic matter (partition coefficient $K o c=25001 . \mathrm{kg}^{-1}$, Howard et al. 1981). Chlordecone has a low volatility (vapour pressure = $2.5 \times 10^{-5} \mathrm{~mm} \mathrm{Hg}$ ), presents high thermodynamic stability and resistance to chemical or biological degradation, involving a high persistence in the environment (Cabidoche et al. 2009). Consequently, it remains in the soil before degradation into at least 5b-hydrochlordecone (Devault et al. 2016). The time to reach the depollution level (at the threshold of quantification of $10 \mu \mathrm{g} \cdot \mathrm{kg}^{-1}$ ) depends on the nature of the soils: a few decades for nitisol, two to three centuries for ferralsol, five to six for andosol (Cabidoche et al. 2009).

Andosols contain amorphous clays, called allophanes, issued from the transformation of volcanic materials with very specific properties. Allophanes present drastically different structures and physical properties compared to usual clays, that is a very high poral volume and an important pores surface. Hygroscopic water contributed to allophanes spherical form, leading them to stack in a three-dimensional fractal labyrinth in which chlordecone could be trapped (Woignier et al. 2007). Due to its trapping ability, allophanes allow chlordecone to reaches runoff and ground waters, and finally end up in the sea. Nitisols are tropical and subtropical deep (iron oxides dominate), red, well-drained soils with clay content of more than $30 \%$. Clays are more aged than andosols, i.e. water content is less important and clays present flatten structure compared to andosols. Nitisols are well-drained type of ferralsol, which are commonly low-draining and muddy due to the high clay content, and more aged than andosols. Andosols and nitisols are particularly abundant in the south of Basse Terre (Guadeloupe) and in the north of Martinique, in the areas where banana plantations occur (Sierra and Desfontaines 2018).

Indeed, in Guadeloupe, approximately 11,400 ha present a high risk of contamination that is $90 \%$ of probability to find chlordecone in these areas. This area represents $25 \%$ of the land surface used for agriculture. In Martinique, this value reaches $40 \%$ of agricultural lands (Direction de l'Alimentation, de l'Agriculture et de la Forêt, data 2018).

Since 2003, several studies conducted in the Lesser Antilles have highlighted the presence of a contamination by chlordecone in soil (Cabidoche et al. 2009), vegetables (Clostre et al. 2015), aquatic and marine organisms (Coat et al. 2006; Bertrand et al. 2013; Coat et al. 2011; Bouchon et al. 2016; Dromard et al. 2016; Monti et al. 2016, Méndez-Fernandez et al. 2018). However, few studies have been conducted on the fate of chlordecone between agricultural fields and marine ecosystems, especially when it arrives in estuarine environments. The studies on Kepone cycling in aquatic environments has been principally conducted in Virginia, because the original production of Kepone began in Hopewell. In 1975, it was discovered that the Kepone factory had not only exposed workers, but also severely contaminated the James River estuary (Nichols 1990; Luellen et al. 2006). 
Chlordecone desorption in the James River estuary has been studied by Nichols (1990) who showed that chlordecone stayed sorbed to organic particles when arriving in estuarine environment in the range of $\mathrm{pH}(7-8)$ and salinity (0.006 to 19.5). To our knowledge, chlordecone desorption has never been studied in the Lesser Antilles that present a particular context due to their tropical pedoclimatic conditions. Our first hypothesis is that chlordecone could be trapped by allophanes, due to their physical structure, and stayed sorbed during its transfer to the marine environment.

Along the James River and at the mouth of this river, contamination of aquatic fauna by chlordecone has been highlighted, starting with plankton, the first link in the trophic food web. Zooplankton is broadly highly impacted by this organochlorine pollution (Bahner et al. 1977; Luellen et al. 2006). Our second hypothesis is that zooplankton could represent a major way of transfer between chlordecone from the water column (adsorbed on terrestrial particles or dissolved) and others organisms from the trophic food-web.

Finally, some studies demonstrated that chlordecone passes through the different levels of the food chain and shows accumulation phenomena, like many other organochlorine pollutants (Bahner et al. 1977). In Guadeloupe and Martinique, the degree of contamination of marine organisms depends mostly on their location around the two islands (Dromard et al. 2016). Fish and crustacean are generally more contaminated when they are located downstream the contaminated watersheds and when they are close to the coast (Dromard et al. 2017). At the same time, detrivorous and carnivorous organisms generally display higher levels of chlordecone contamination than other trophic groups (Luellen et al. 2006; Dromard et al. 2017). Our third hypothesis is that chlordecone concentrates in marine organisms, depending on their location (close or far from the source of pollution) and on their feeding ecology.

The principal objective of the present study is to compile the results of recent studies on the environmental fate of chlordecone from estuaries to the marine ecosystems in the Lesser Antilles, with two main objectives: 1) to study chlordecone desorption as its arrival in the marine environment, 2) to evaluate the transfer of chlordecone in marine trophic food web, from plants to top predators. To do so, three studies recently conducted in Guadeloupe and Martinique are presented in the present work.

\section{Material and Methods}

\section{Experimental protocol to measure chlordecone desorption on allophanes}

A selected allophanic soil (6.1\% w.w.) historically contaminated was sampled in Martinique and sieved on 2 mm-mesh stainless steel sieve. Samples of $1.5 \mathrm{~g}$ of soil has been incubated at dark and moderately stirred in glass vial during $24 \mathrm{~h}$ in artificial sea salted water at 0,10, 20 and 35 psu. Artificial seawater results from a mixture of Vittel ${ }^{\circledR}$ mineral water and coral reef "Instant ocean" sea salt from Aquarium Systems ${ }^{\circledR}$. Each experiment was performed in triplicates.

In order to estimate chlordecone adsorption on the glass of the vials, three positive controls were implemented with Vittel water mixed with chlordecone up to a concentration of $0.1 \mu \mathrm{g} .1^{-1}$.

After incubation, suspended soils were filtered on Solid Phase Micro-Extraction (SPME) glass fiber filter (PDMS $100 \mu \mathrm{m}$ Merlin): soil was lyophilized, then extracted in a microwave extractor (4 ml of dichloromethane, 30 watts, 10 minutes) and filtered again on a glass fiber filter in order to collect the organic extract. 
The latter was partially evaporated under $70 \%$ agitation and $51 \%$ vacuum (900 mb), using a Rapidvap provided by Labocongo ${ }^{\circledR}$, then reconditioned and fully evaporated under nitrogen stream. Extracts were reconstituted in 1 $\mathrm{ml}$ of acetonitrile and kept frozen until analysis.

Internal ${ }^{13} \mathrm{C}$ chlordecone was added to filtered water (about $150 \mathrm{ml}$ ) then liquid-liquid extracted with $3 \mathrm{x} 10 \mathrm{ml}$ of dichloromethane. Extracts, dried on $\mathrm{Na}_{2} \mathrm{SO}_{4}$, were partially evaporated under $70 \%$ agitation and $51 \%$ vacuum $(900 \mathrm{mb})$ then reconditioned and fully evaporated under nitrogen stream. Extracts were reconstituted in $1 \mathrm{ml}$ of acetonitrile and kept frozen until analysis. Extraction recovery was respectively of $106 \pm 6 \%$ and $111 \%$. For this experiment, solvents (dichloromethane, acetonitrile) were at least of analytical grade and provided by ICS (Belin-Beliet ${ }^{\circledR}$, France). Certified solid standards for chlordecone were obtained from Cluzeau Info Labo.

Concentrations of chlordecone in water and soil were measured by liquid chromatography (Agilent series 1200) using in tandem a mass spectrometer detector (Agilent ${ }^{\circledR}$ 6410a) that was provided by Agilent (Santa Clara, California, USA).

\section{Samplings protocol to evaluate zooplankton contamination}

Samples of zooplankton and seawater were collected at the mouth of two rivers in Guadeloupe (Rivière Grande Anse and Rivière du Grand Carbet) and two rivers in Martinique (Rivière Monsieur and Rivière Rouge) in December 2010. A second sampling campaign was done in Guadeloupe in May 2011. These four rivers have been chosen due to their high level of contamination by chlordecone. Samplings were conducted along three transects oriented from the coast to the open sea, using a $500 \mu \mathrm{m}$-meshed net for the plankton and glass bottles for seawater. On each site, nine stations were chosen to sample zooplankton and seawater $(\mathrm{n}=3$ replicates at each station for each compartment). Samples were freeze-dried before analysis.

Quantification of chlordecone in zooplankton and seawater was conducted by the Center for Analytical Research and Technology at Liege University (CART, Belgium). Lipids and chlordecone were extracted with an accelerated solvent extractor using n-hexane-dichloromethane (90:10; v:v). The extracts were then dried under nitrogen flow until a constant weight is obtained. $3 \mathrm{ml} \mathrm{n}$-hexane and a surrogate marker (PCB congener 112), at a concentration of $50 \mathrm{pg} . \mu \mathrm{l}^{-1}$, were added. Then, the extracts underwent an acid clean-up carried out with $2 \mathrm{ml}$ of sulphuric acid (98-100\%) in order to eliminate organic compounds (lipids, lipoproteins,...). Finally, the eluates were evaporated under an almost dry nitrogen stream. $100 \mu \mathrm{l}$-hexane and $100 \mu 1$ PCB 209 congener, used as an internal standard at a concentration of $50 \mathrm{pg} . \mu \mathrm{l}^{-1}$, were added to the samples before injection. The analyses were performed by GCMS-MS (ThermoQuest ITQ 1100 ion trap). With this method, the lower limit of quantification (LOQ) was $0.010 \mu \mathrm{g} . \mathrm{kg}^{-1}$ w.w. for zooplankton and $0.010 \mu \mathrm{g} . \mathrm{l}^{-1}$ for seawater (Monti et al. 2017).

\section{Samplings protocol to evaluate trophic-food web contamination}


To study the contamination of marine food webs by chlordecone, samplings were conducted at Petit-Bourg in Guadeloupe, in three habitats: mangrove, seagrass beds (located at $500 \mathrm{~m}$ from the coast) and coral reefs $(4 \mathrm{~km}$ from the coast), between January 2014 and February 2015. On each habitat, sediment, Superficial Sediment Layer (SSL), Suspended Organic Matter (SOM), vegetal matter (macroalgae and seagrass) and consumers from different trophic levels (primary consumers, secondary consumers, top predators) were collected. The classification of species into trophic group was done according to the literature (Randall 1967, Froese and Pauly 2017). The full list of collected species is given in S1 Table. Macroalgae, fishes and crustaceans were collected by hand, spearfishing or using nets in seagrass beds and mangroves. Whenever possible, three replicates were made for each species. Each individual was rinsed, measured (total length (TL) in centimeters) and weighed (w.w. in grams). For each organism, a piece of flesh was collected and frozen $\left(-18^{\circ} \mathrm{C}\right)$ until analyses.

To sample the suspended organic matter (SOM), seawater was collected in the three habitats in acid-cleaned plastic drums. Water was then filtered on Whatman ${ }^{\circledR} \mathrm{GF} / \mathrm{F} 47 \mathrm{~mm}$ filters. Sediments were recovered using a corer to a depth of about $20 \mathrm{~cm}$. Superficial sediment layer (SSL) was sampled on the first $2 \mathrm{~cm}$ of sediment. Concentrations in chlordecone were quantified by LABOCEA (Plouzané, France) with liquid chromatography coupled to mass spectrometry in tandem (UPLC-MS/MS). The lower LOQ with this method was $1 \mu \mathrm{g} \cdot \mathrm{kg}^{-1}$ (w.w.) for organic material and $10 \mu \mathrm{g} . \mathrm{kg}^{-1}$ (w.w.) for sediment.

\section{Results}

\section{Chlordecone desorption on allophanes}

No adsorption on the glass of the vials has been observed on controls.

Initial concentration of chlordecone measured in soil was $957 \pm 13.2 \mu \mathrm{g} . \mathrm{kg}^{-1}$ that is about $1.145 \mu \mathrm{g}$ of chordecone in each sample of $1.5 \mathrm{~g}$ of soil. After $24 \mathrm{~h}$ of incubation, the maximal desorption of chlordecone was observed in the minimal salinity conditions ( 0 psu) while the minimal desorption was observed in the maximal salinity condition (35 psu) (Table 1).

Table 1 Concentrations of chlordecone ([CDC]) measured in soil after $24 \mathrm{~h}$ of incubation. Initial concentration of chlordecone in soil was $957 \pm 13.2 \mu \mathrm{g} . \mathrm{kg}^{-1}$. SD: Standard Deviation; RSD: Relative Standard Deviation.

\begin{tabular}{ccccc}
\hline & & {$[\mathrm{CDC}]$} & Mean [CDC] \pm SD & RSD \\
\hline Salinity (psu) & Replicates & $\mu \mathrm{g} \cdot \mathrm{kg}^{-1}$ & $\mu \mathrm{g} \cdot \mathrm{kg}^{-1}$ & $\%$ \\
\hline \multirow{2}{*}{0} & 1 & 729 & & \\
& 2 & 983 & $788 \pm 173.1$ & 22.0 \\
& 3 & 653 & & \\
\multirow{2}{*}{10} & 1 & 905 & & 11.6 \\
& 2 & 733 & $799 \pm 92.6$ & \\
& 3 & 759 & & \\
\multirow{2}{*}{20} & 1 & 821 & & \\
& 2 & 902 & $837 \pm 57.8$ & 20.8 \\
& 3 & 790 & & \\
\hline \multirow{2}{*}{35} & 1 & 674 & & \\
& 2 & 1002 & $814 \pm 169.2$ & \\
& 3 & 766 & & \\
\hline
\end{tabular}


After $24 \mathrm{~h}$ of incubation, $78 \%$ of the initial quantity of chlordecone was still adsorbed on soil in the freshwater condition (0 psu) and $90 \%$ for the marine condition (35 psu) (Fig. 1). About $20 \%$ of the initial quantity of chlordecone was desorbed from soil in estuarine conditions (10 and $20 \mathrm{psu}$ ).

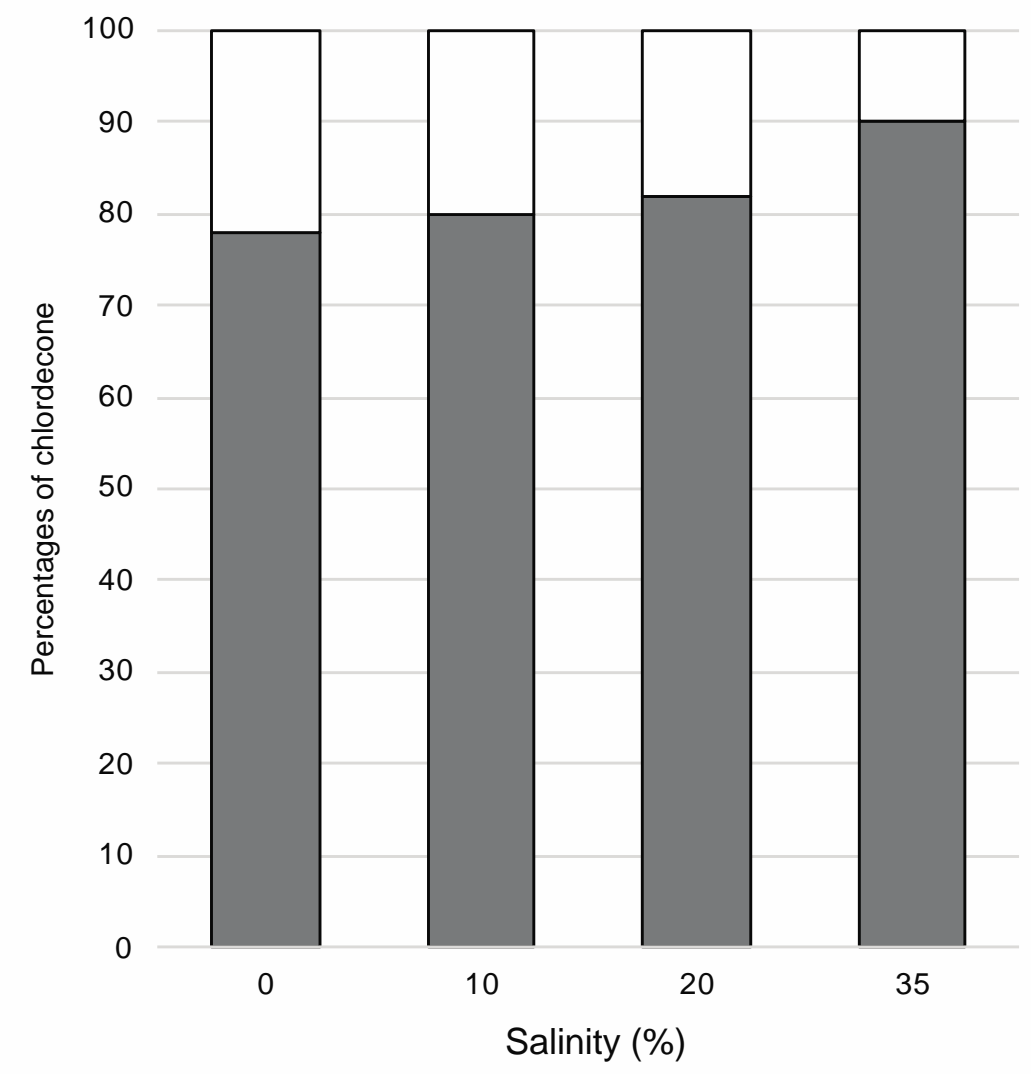

Fig. 1 Percentages of chlordecone in water (white) and in soil (grey) related to salinity after 24 h of incubation.

\section{Contamination of the planktonic compartment}

In Martinique, the minimal concentration of chlordecone found in zooplankton was $22 \mu \mathrm{g} . \mathrm{kg}^{-1}$ (Rivière Rouge) while the maximal concentration was measured at the mouth of Rivière Monsieur $\left(272 \mu \mathrm{g} \cdot \mathrm{kg}^{-1}\right)$. In Guadeloupe, concentrations in chlordecone varied between 40 and $306 \mu \mathrm{g} \cdot \mathrm{kg}^{-1}$ (Fig. 2). Concentrations of chlordecone in seawater were under the LOQ in $53 \%$ of the studied stations. In the other stations, concentrations varied from 0.01 to $0.053 \mu \mathrm{g} . \mathrm{L}^{-1}$. No correlation was found between the concentration of chlordecone measured in seawater and zooplankton.

Temporal variations in the level of contamination of zooplankton were tested in Guadeloupe. No statistical significant difference was found on the level of contamination in zooplankton between samples collected at the end of the dry season (May) and those collected at the end of the wet season (December), according to the two sites in Guadeloupe.

Spatial variations in the level of contamination of zooplankton were tested between the four sites (two in Martinique and two in Guadeloupe) sampled in December 2010. Mean concentrations of chlordecone in zooplankton show significant spatial differences (Kruskal-Wallis, $X^{2}=13.9, p=0.002$ ). These spatial 
differences were globally due to the lower concentrations of chlordecone measured in zooplankton at the mouth of Rivière Rouge compared to the other sites.

The bioconcentration factor $(\mathrm{BCFw})$, calculated as the ratio between concentrations of chlordecone measured in zooplankton and those measured in seawater, varied from 440 and 27200 (Table 2).

Table 2 Mean concentrations of chlordecone ( $\min$ - max) measured in zooplankton (in $\mu \mathrm{g} \cdot \mathrm{kg}^{-1}$ w.w.), seawater (in $\mu \mathrm{g} . \mathrm{l}^{-1}$ ) and mean bioconcentration factors (BCFw) at the mouth of four rivers. WS: end of the wet season (December), DS: end of the dry season (may), n: number of samples, “-“ indicates absence of measures.

\begin{tabular}{ccccccc}
\hline Islands & Rivers & Seasons & $\mathrm{n}$ & Zooplankton & Seawater & BCFw \\
\hline Martinique & Rivière Rouge & WS & 9 & $62.3(22-99)$ & $0.028(0.01-0.05)$ & $4320(440-9900)$ \\
Martinique & Rivière Monsieur & WS & 9 & $164.3(79-272)$ & 0.01 & 27200 \\
Guadeloupe & Grande Anse & WS & 9 & $104(40-294)$ & $0.023(0.02-0.027)$ & $5338(2095-10889)$ \\
Guadeloupe & Grande Anse & DS & 9 & $167.8(79.5-271.8)$ & - & - \\
Guadeloupe & Grand Carbet & WS & 9 & $133.0(50.9-231.7)$ & - & - \\
Guadeloupe & Grand Carbet & DS & 9 & $164.7(100-306)$ & $0.027(0.017-0.053)$ & $7422(2509-14647)$ \\
\hline
\end{tabular}

Mean BCFw was maximal at the mouth of Rivière Monsieur in Martinique. The three other sites reached similar order of magnitude: 4320 at Rivière Rouge, 7422 at Grand Carbet and 5338 at Grande Anse (Fig. 2). 


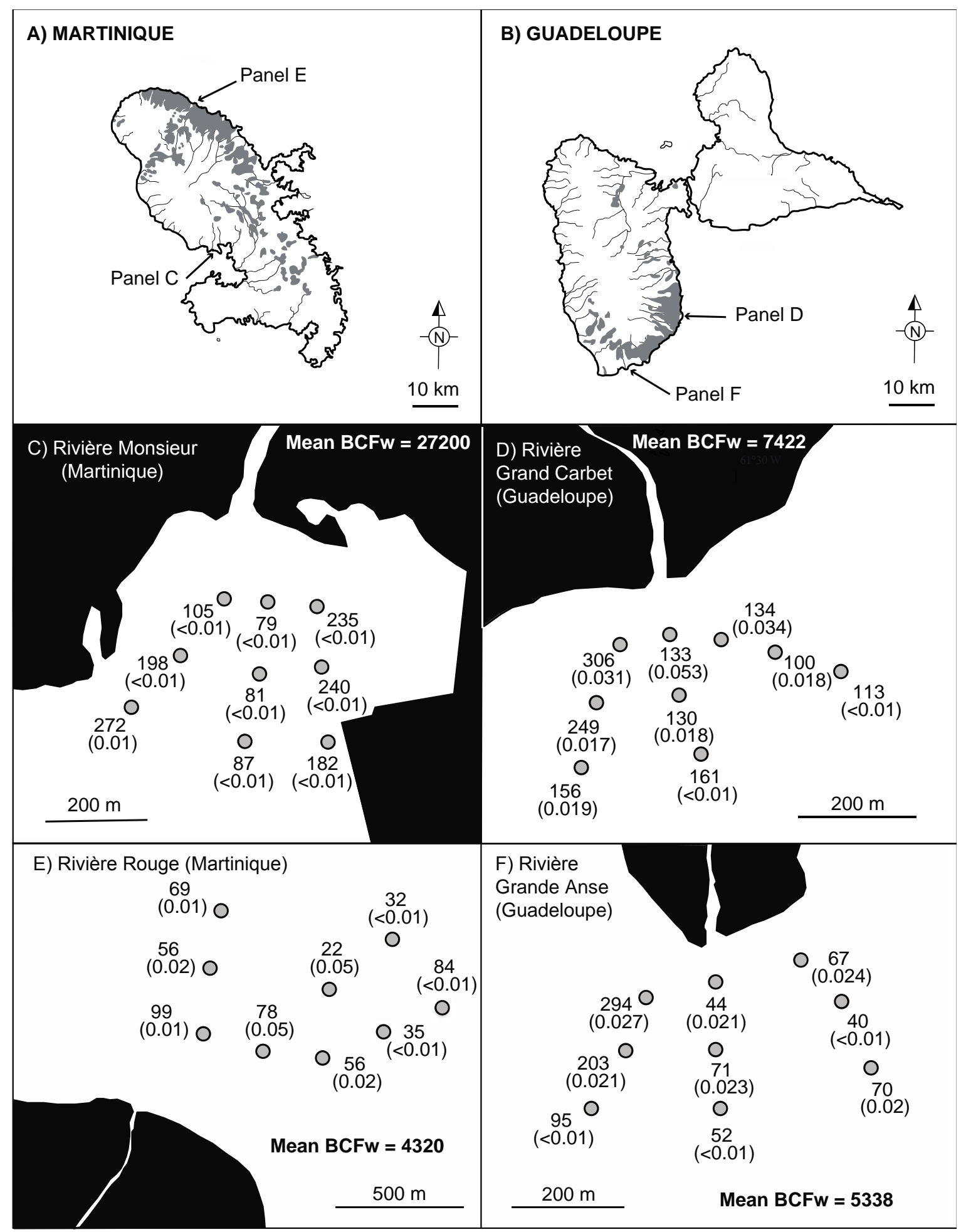

Fig. 2 Mean concentration of chlordecone measured in zooplankton (in $\mu \mathrm{g} . \mathrm{kg}^{-1}$ w.w.) and seawater (into brackets, in $\mu \mathrm{g} . \mathrm{l}^{-1}$ w.w.) in Martinique (A) and in Guadeloupe (B) at the mouth of four rivers (C to $\left.\mathrm{F}\right)$. BCFw: Bioconcentration factor (data from Monti et al. 2012); grey surfaces in A and B panels indicate soils contaminated by chlordecone. 


\section{Contamination of the trophic food web}

Concentrations in chlordecone were measured in different sources of matter and marine organisms in three marine habitats: mangrove, seagrass beds and coral reefs (Fig. 3).
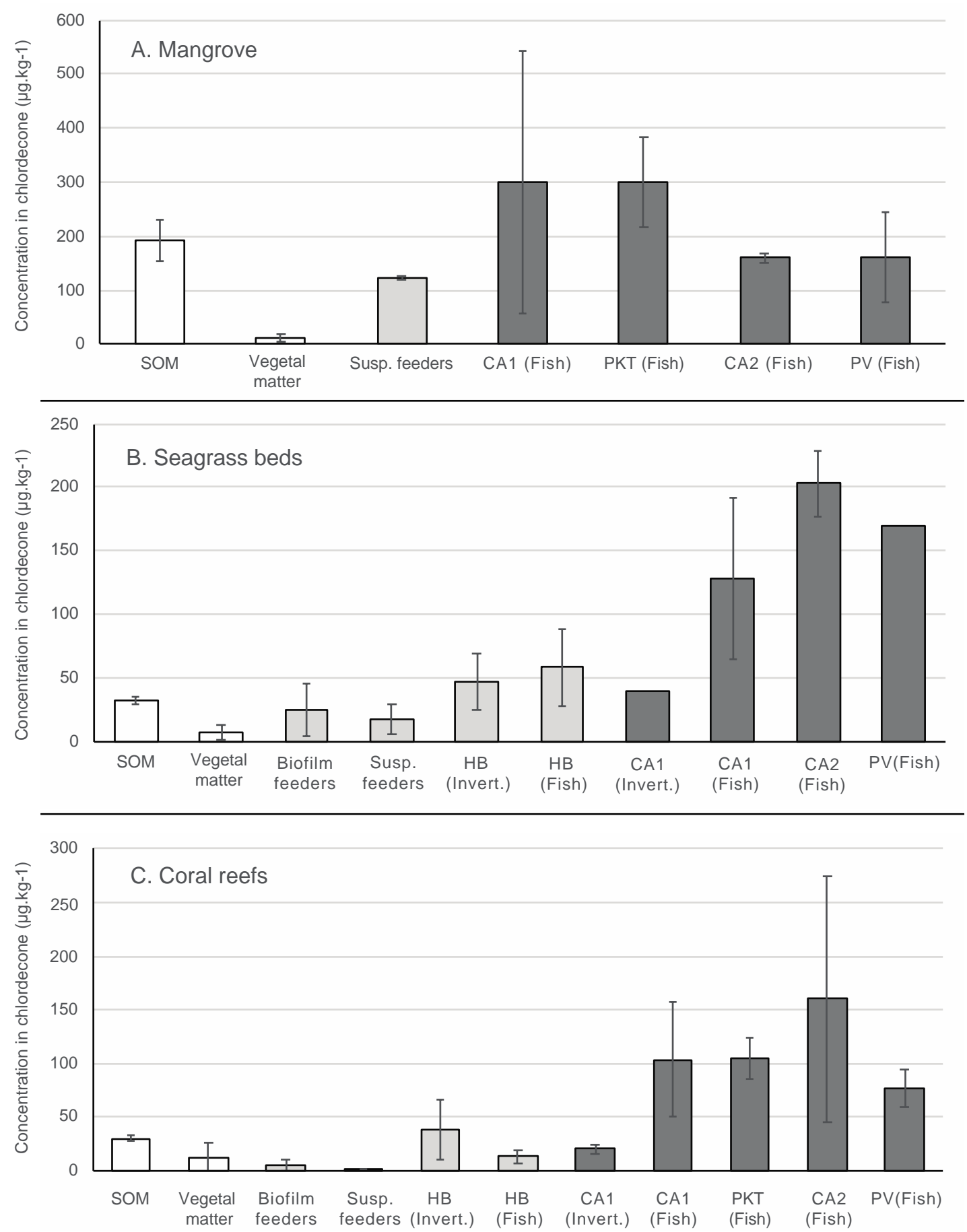

Fig. 3 Mean concentration of chlordecone $\pm \mathrm{SD}$ (in $\mu \mathrm{g} \cdot \mathrm{kg}^{-1}$ ) measured in sources of carbon (in white, SOM: Suspended Organic Matter; Vegetal matter: algal turf, macroalgae, seagrass), primary consumers (in light grey, Susp. Feeders: suspension feeders, HB: herbivores) and secondary consumers (in dark grey, CA1: invertebrate feeders, PKT: planktivores, CA2: fish and invertebrate feeders, PV: piscivores), in mangrove (A), seagrass beds (B) and coral reefs $(\mathrm{C})$. 
Mean concentrations per trophic category were calculated in pooling all individuals from similar trophic group. Concentrations in chlordecone in sediment and superficial sediment layer (SL) were found under the limit of quantification $\left(10 \mu \mathrm{g} \cdot \mathrm{kg}^{-1}\right)$. However, chlordecone was found in SOM and vegetal matter in the different habitat. SOM exhibited the highest values among the different sources of carbon. Primary consumers, including biofilm feeders, suspension feeders and herbivorous organisms, presented intermediate mean concentrations of chlordecone from $122.3 \pm 3.8 \mu \mathrm{g} . \mathrm{Kg}^{-1}$ in mangrove to $17.0 \pm 22.0 \mu \mathrm{g} . \mathrm{Kg}^{-1}$ in coral reefs. Secondary consumers, that are carnivorous organisms (invertebrates feeders, invertebrates and fish feeders and piscivorous), showed the highest mean concentrations of chlordecone among the studied trophic categories from $232.6 \pm 172.3 \mu \mathrm{g}^{-\mathrm{Kg}^{-1}}$ in mangrove to $91.9 \pm 57.6 \mu \mathrm{g} . \mathrm{Kg}^{-1}$ in coral reefs. In each habitat, significant differences in the mean concentrations of chlordecone were found between the food sources (SOM, vegetal matter) and the trophic categories (primary consumers and secondary consumers) (Table 3). In mangrove, multiple post-hoc comparisons tests indicated that differences of chlordecone concentrations between trophic categories are due to the low value in vegetal matter. In this habitat, SOM, primary and secondary consumers showed similar levels of contamination but were statistically different from the level in vegetal matter. In seagrass beds and coral reefs, the patterns of contamination were similar: SOM, vegetal matter and primary consumers were not statistically different according to their level of contamination. However, these three trophic categories significantly displayed lower concentrations of chlordecone than secondary consumers (Table 3).

Table 3 Mean concentrations of chlordecone $\left( \pm\right.$ SD) in $\mu \mathrm{g} \cdot \mathrm{kg}^{-1}$ measured in food sources (SOM and vegetal matter), primary consumers and secondary consumers. Differences in chlordecone concentrations between the trophic categories were tested with a Kruskal-Wallis test. Letters indicate the results of multiple comparisons conducted with post-hoc tests.

\begin{tabular}{cccc}
\hline Trophic categories & Mangrove & Seagrass beds & Coral reefs \\
\hline SOM & $191.3 \pm 38.5^{b}$ & $31.7 \pm 2.9^{a}$ & $30.3 \pm 2.1^{a}$ \\
Vegetal matter & $12.3 \pm 6.4^{a}$ & $6.8 \pm 5.6^{a}$ & $12.3 \pm 13.5^{a}$ \\
Primary consumers & $122.3 \pm 3.79^{b}$ & $34.6 \pm 25.9^{a}$ & $17.0 \pm 22.0^{a}$ \\
Secondary consumers & $232.6 \pm 172.3^{b}$ & $147.5 \pm 66.0^{b}$ & $91.9 \pm 57.6^{b}$ \\
$X^{2}$ & 15.1 & 44.1 & 35.6 \\
p values & 0.002 & $<0.0001$ & $<0.0001$ \\
\hline
\end{tabular}

\section{Discussion}

In the Lesser Antilles, all the environmental compartments that have been in contact with chlordecone present a signal of contamination: agricultural soil, rivers, seawater, zooplankton and fauna from the marine food webs. In the present work, the experiments conducted to study the behavior of chlordecone during its arrival in estuarine and marine environments show that molecules stay strongly linked to the particles of terrestrial organic matter, whatever the salinity ( 0 to $35 \mathrm{psu}$ ). About $20 \%$ of the initial quantity of chlordecone was desorbed from soil in estuarine conditions (10 and $20 \mathrm{psu}$ ) and $10 \%$ was released in marine conditions (35 psu). Thus, even if furthers 
investigations should be conducted to verify this affirmation, marine conditions seem to be the least conducive to desorption. These results are in accordance with those of Nichols (1990), who demonstrated that once chlordecone is sorbed it stays adsorbed in the range of $\mathrm{pH}$ (7-8) and salinity (0.006 to 19.5). Bakir et al. (2014) demonstrated that salinity generally does not affect desorption rates of persistent organic pollutants (POP), however their study was conducted on sorption of POP on microplastics. The capacity of POP sorption and desorption on allophanes could be different. In the present study, salinity appears to limit chlordecone desorption because of a process which needs furthers investigations. The present experiments could explain the high concentrations of chlordecone measured in the suspended organic matter (SOM), collected after filtration of seawater in the coastal areas (from 28 to $233 \mu \mathrm{g} \cdot \mathrm{kg}^{-1}$ ). Chlordecone was not encountered in superficial sediment layers and marine sediments cores (all samples presented concentrations inferior to the limit of quantification: 10 $\left.\mu \mathrm{g} \cdot \mathrm{kg}^{-1}\right)$. These results could be due to the fact that some samples of sediments collected in the present study were poor in organic matter (for example, less of $2 \%$ of OM in sediments collected in coral reefs). Indeed, the level of contamination of sediments is generally associated with the nature of sediment: organic-rich sediment has much greater capacity to sorb chlordecone than organic-poor sand or kaolinite (O'Connor and Connolly 1980). Bodiguel et al. (2011) and Robert (2012) also found a very low level of contamination for these two compartments in a bay in Martinique (22 samples, all were $<0.5 \mu \mathrm{g} . \mathrm{kg}^{-1}$ ). In 2005, Bocquené and Franco found a disparity between the concentrations of chlordecone measured in sediment $\left(<10 \mu \mathrm{g}_{\mathrm{kg}}{ }^{-1}\right)$ and SOM $(52$ and 22 $\left.\mu \mathrm{g} . \mathrm{kg}^{-1}\right)$. Chlordecone can be transferred to estuaries and the marine environment in particulate form (Crabit et al. 2016) via SOM to which it is firmly attached. This suspended matter does not seem to settle on the bottom directly when it arrives at sea, since the sediment compartment is very little affected by the contamination. Several hypothesis could explain these observations: 1) contaminated SOM is constituted by very fine and low density particles which may settle far from estuarine and coastal areas (but this explanation cannot be plausible in semi-enclosed bays), 2) contaminated SOM may be directly consumed in the water column by planktonic compartment upon arrival in the marine environment, 3) contaminated SOM may settle in estuaries and coastal areas but may be rapidly degraded by microorganisms in the sedimentary compartment, 4) samples were collected during the wet season, which can induce intense rainfall and disturbances of estuarine and coastal waters, preventing sedimentation of contaminated SOM (Eggleton and Thomas 2004; Noegrohati et al. 2008).

Levels of contamination of zooplankton compartment were investigated to verify the second hypothesis on chlordecone pathway (see above). Zooplankton is closely linked and in direct contact to SOM in estuarine and coastal waters. Indeed, previous studies have highlighted the sensibility to this compartment towards organochlorine pollutants, probably due to its lipid content (Jordan 1979; Day 1990; Nichols 1990). Nichols (1990) measured a mean concentration equal to $4800 \mu \mathrm{g} \cdot \mathrm{kg}^{-1}$ in zooplankton from the James River estuary. Coat et al. (2011) reported a mean concentration equal to $5100 \mu \mathrm{g} \cdot \mathrm{kg}^{-1}$ in the river mouth and $3500 \mu \mathrm{g} \cdot \mathrm{kg}^{-1}$ in the coastal waters of Guadeloupe. In the present study, concentrations of chlordecone measured in zooplankton were considerably lower and varied between 22 and $306 \mu \mathrm{g} \cdot \mathrm{kg}^{-1}$. Concentrations of chlordecone in zooplankton also spatially varied. The lowest concentrations were observed in front of Rivière Rouge, probably due to the exposure of the site to swell on this Atlantic coast. No temporal variations of chlordecone concentrations were observed between zooplankton collected at the end of the wet season and those collected at the end of the dry season. However, the number of samples was relatively low and samples were taken in the same day during each campaign. Because the planktonic compartment displays very short turn-over, further sampling effort should 
highlight temporal variations in the level of chlordecone contamination of zooplankton. Bioconcentration factors $(\mathrm{BCFW})$ were calculated as the ratio between concentrations of chlordecone in zooplankton and those in seawater. The highest BCFw was found at the mouth of Rivière Monsieur, probably due to its high degree of confinement (semi-enclosed bay). Zooplankton is a keystone component of both marine and rivers systems. It represents a link between invertebrates and fish by providing food and by recycling essential nutrients through feeding on living and detrital material. The accumulation of organochlorine pollutants in zooplankton is a severe threat to ecosystems and a potential way of transfer of the molecule along marine and freshwater food webs.

Bioaccumulation phenomena of chlordecone have been demonstrated experimentally (Bahner 1977) and in the field (Dromard et al. 2018). Two processes of bioaccumulation were demonstrated in the present study. In mangrove, the ambient level of contamination is high (SOM: $191.3 \mu \mathrm{g}^{\mathrm{kg}}{ }^{-1}$ ) and this value from the basis of the trophic food web is not statistically different from the other trophic categories (excepted with vegetal matter). Indeed, in mangrove, the entire trophic food web exhibits high concentrations of chlordecone, reflecting the contamination of the baseline. This first way of contamination indicates a prevalence of a contamination "by bath", i.e. by contact between organisms (via teguments and gills) and contaminated surrounding waters. In seagrass beds and coral reefs, food sources and primary consumers shared similar level of contamination that were significantly different from those of the secondary consumers. In these two habitats, a phenomenon of bioamplification, i.e. a contamination by trophic way, is highlighted. The introduction of carnivory in fish diet is linked to a significant increase in the chlordecone concentrations of marine organisms, probably due to the higher lipid content in the preys. In the Lesser Antilles, the degree of contamination of marine systems by chlordecone was drastically lower than that measured in the James River estuary, due to the difference of pollution discharge between the two sites. However, the majority of the studied species were impacted by chlordecone and showed concentrations above the maximal residue limit (LMR) authorized by the French food and safety authorities for the consumption and the commercialization of seafood products ( $\mathrm{LMR}=20 \mu \mathrm{g} \cdot \mathrm{kg}^{-1}$ ).

The variations among species from similar trophic category were sometimes very high, suggesting that other processes could influence the level of contamination of marine fishes, such as their physiology, their size or their movement among the different habitats. Indeed, Luellen et al. (2006) indicated that fish ecology could considerably influence the level of contamination of marine fishes, especially for migratory species that spend a period of the year in an estuarine environment.

To conclude, molecules of chlordecone can reach marine ecosystems with two principal processes. Firstly, dissolved molecules of chlordecone can infiltrate ground waters during percolation process and join marine environment with resurgences inside rivers or in the sea (Crabit et al. 2016). In the present study, this pollution was highlighted by the concentrations of chlordecone measured in seawater samples. Secondly, due to its strong affinity with soil particle (allophane or others terrestrial particles), molecules of chlordecone can reach runoff waters, rivers and estuaries by leaching of the contaminated soil throughout the erosion process of the catchment (Crabit et al. 2016). When chlordecone arrive in marine environment, it seems to stay sorbed on allophanes and this fact could be similar with other organic compounds, as salinity generally does not affect desorption rates (Bakir et al. 2014). Chlordecone, adsorbed or dissolved, is then integrated in SOM and zooplankton. These two compartments are located at the base of trophic food-web and contribute to the contamination of the entire food chain, via contact or trophic way. 
In perspectives, several aspects of chlordecone transfer between terrestrial, rivers and marine ecosystems should be developed in future studies. The low proportion of chlordecone desorbed from allophanes requires further studies on the physical and chemical behavior of allophanes when arriving in marine environments. The potential ways of chlordecone degradation in marine sediment could also be investigated in order to understand the low concentrations of chlordecone found in marine sediment. Measurements of chlordecone metabolites in the sediment could help with the understanding of a potential bacterial degradation in this compartment. Finally, studies on the kinetic of contamination versus decontamination in marine fauna could be useful to explain the high variations in the concentrations of chlordecone between species and individuals.

\section{Acknowledgements}

The authors express thanks to the institutions that gave financial supports to realize this study: Office de l'Eau of Guadeloupe and Martinique, ONEMA (AFB), DEAL Guadeloupe and Martinique (for the program CLIPPER and the study on the plankton contamination by chlordecone), Prefecture of Martinique (ChloHal program).

\section{References}

Bahner LH, Wilson AJ, Sheppard JM, Patrick JM, Goodman LR, Walsh GE (1977) Kepone® Bioconcentration, accumulation, loss and transfer through estuarine food chains. Chesap Sci 18: 299-308

Bakir A, Rowland SJ, Thompson RC (2014) Transport of persistent organic pollutants by microplastics in estuarine conditions. Estuar Coast Mar Sci 140: 14-21

Bertrand JA, Guyader O, Reynal L (2013) Characterization of the contamination of the halieutic fauna by chlordecone around Guadeloupe (surveys 2008 to 2011). Ifremer, 39 pp (in French) http://archimer.ifremer.fr/doc/00136/24762

Bodiguel X, Bertrand JA, Frémery J (2011) Transfert of the chlordecone in the trophic foodwebs of commercial marine species in the Lesser Antilles (Chloretro). Ifremer, 46 pp (in French) http://archimer.ifremer.fr/doc/00036/14684/

Bocquené G, Franco A (2005) Pesticide contamination of the coastline of Martinique. Marine Pollut Bull 21: 9511-9521

Boucher O, Simard MN, Muckle G, Rouget F, Kadhel P, Bataille H, Chajès V, Dallaire R, Monfort C, thomé JP, Multigner L, Cordier S (2013) Exposure to an organochlorine pesticide (chlordecone) and development of 18-month-old infants. NeuroToxicology 35: 162-168

Bouchon C, Lemoine S, Dromard CR, Bouchon-Navaro Y (2016) Level of contamination by metallic trace elements and organic molecules in the seagrass beds of Guadeloupe Island. Environ Sci Pollut Res 23: $61-72$

Cabidoche YM, Achard R, Cattan P, Clermont-Dauphin C, Massat F, Sansoulet J (2009) Long-term pollution by chlordecone of tropical volcanic soils in the French West Indies: A simple leaching model accounts for current residue. Environ Pollut 157: 1697-1705

Clostre F, Letourmy P, Lesueur-Jannoyer M (2015) Organochlorine (chlordecone) uptake by root vegetables. Chemosphere 118: 96-102

Coat S, Bocquené G, Godard E (2006) Contamination of some aquatic species with the organochlorine pesticide chlordecone in Martinique. Aquat Living Resour 19: 181-187 
Coat S, Monti D, Legendre P, Bouchon C, Massat F, Lepoint G (2011) Organochlorine pollution in tropical rivers (Guadeloupe): role of ecological factors in food web bioaccumulation. Environ Pollut 159: 1692 1701

Crabit A, Cattan P, Colin F, Voltz (2016) Soil and river contamination patterns of chlordecone in a tropical volcanic catchment in the French West Indies (Guadeloupe). Environ Pollut 212: 615-626

Day KE (1990) Pesticide residues in freshwater and marine zooplankton: a review. Environ Pollut 67: $205-222$

Devault DA, Laplanche C, Pascaline H, Bristeau S, Mouvet C, Macarie H (2016) Natural transformation of chlordecone into 5b-hydrochlordecone in French West Indies soils: statistical evidence for investigating long-term persistence of organic pollutants. Environ Sci Pollut Res 23: 81-97

Dromard CR, Bodiguel X, Lemoine S, Bouchon-Navaro Y, Reynal L, Thouard E, Bouchon C (2016) Assessment of the contamination of marine fauna by chlordecone in Guadeloupe and Martinique (Lesser Antilles). Environ Sci Pollut Res 23: 73-80

Dromard CR, Guéné M, Bouchon-Navaro Y, Lemoine S, Cordonnier S, Bouchon C (2017) Contamination of marine fauna by chlordecone in Guadeloupe: evidence of a seaward decreasing gradient. Environ Sci Pollut Res 25: 14294-14301

Dromard CR, Bouchon-Navaro Y, Cordonnier S, Guéné M, Harmelin-Vivien M, Bouchon C (2018) Different transfer pathways of an organochlorine pesticide across marine tropical food webs assessed with stable isotope analysis. PLoS ONE 13(2): e0191335

Eggleton J, Thomas KV (2004) A review of factors affecting the release and bioavailability of contaminants during sediment disturbance events. Environ Int 30: 973-980

Epstein SS (1978) Kepone - Hazard evaluation. Sci Total Environ 9: 1-62

Froese R, Pauly D (2017) FishBase: World Wide Web electronic publication. Available: www.fishbase.org.

Jordan RA, Goodwin PA, Sutton CE, Lascara VJ, VanVeld PA, Carpenter RK (1979) An evaluation of the Kepone contamination of the plankton of the James River. Virginia Institute of Marine Science, $51 \mathrm{pp}$

Kadhel P, Monfort C, Costet N, Rouget F, Thomé JP, Multigner L, Cordier S (2014) Chlordecone exposure, length of gestation, and risk of preterm birth. Am J Epidemiol 179(5): 536-544

Luellen DR, Vadas GG, Unger MA (2006) Kepone in James River fish: 1976-2002. Sci Total Envion 358: 286297

Méndez-Fernandez P, Kiska JJ, Heilthaus MR, Beal A, Vandersarren G, Caurant F, Spitz J, Taniguchi S, Montone RC (2018) From banana fields to the deep blue: assessment of chlordecone contamination of oceanic cetaceans on the eastern Caribbean. Mar Poll Bull 137: 56-60

Monti D, Forget-Leray J, Lagadic L, Thomé JP, Boulangé-Lecomte C, Zimmerman-Chancerel G, Géraudie P, Louvet M, Vassaux D, Boucher P, Herman F, Renia L, Yang-Ting L, Letellier J, Dromard C, Urvoix L (2012) Vulnerability of Guadeloupe and Martinique freshwater nurseries to chlordecone contamination in water. Report UAG/ONEMA/ODE/OEG/DEAL Martinique/DEAL Guadeloupe, 43 pp (in French)

Monti D, Rey P, Thomé JP (2016) Contamination of freshwater fauna. In: Lesueur Jannoyer M, Cattan P, Woignier T (ed), Clostre Florence (ed.) Crisis management of chronic pollution: contaminated soil and human health. CRC Press, Boca Raton, pp 91-103

Monti D, Rey P, Thomé JP (2017) Contamination of freshwater fauna. In: Jannoyer M, Cattan P, Woignier T, Clostre F (eds) Crisis Management of Chronic Pollution, 1st edn. CRC Press, Boca Raton, pp 91-103 
Multigner L, Ndong JR, Giusti A, Romana M, Delacroix-Maillard H, Cordier S, Jégou B, Thome JP, Blanchet P (2010) Chlordecone exposure and risk of prostate cancer. Am J Clin Oncol 28: 3457-3462

Multigner L, Kadhel P, Rouget F, Blanchet P, Cordier S (2016) Chlordecone exposure and adverse effects in French West Indies populations. Environ Sci Pollut Res 23: 3-8

Nichols MM (1990) Sedimentologic fate and cycling of Kepone in an estuarine system: example from the James River estuary. Sci Total Environ 97/98: 407-440

Noegrohati S, Narsito, Hadi S, Sanjayadi (2008) Fate and behavior of organochlorine pesticides in the Indonesian tropical climate: a study in the Segara Anakan estuarine ecosystem. Clean 36: 767-774

O’Connor DJ, Connolly PJ (1980) The effect of concentration of adsorbing solids on the partition coefficient. Water Res 14: 1517-1523

Randall JE (1967) Food habits of reef fishes of the West Indies. Stud Trop Oceanogr 5: 665-847

Robert S (2012) History of chlordecone contamination of coastal sediments in the French West Indies (ChloSed). Ifremer, 93 pp (in French)

Sierra J, Desfontaines L (2018) Les sols de la Guadeloupe-Génèse, distribution et propriétés. Rapport INRA Guadeloupe, 23 pp (in French)

Woignier T, Pochet G, Doumenc H, Dieudonné P, Duffours L (2007) Allophane: A natural gel in volcanic soils with interesting environmental properties. J Sol-Gel Sci Technol 41(1): 25-30 